IRYNA KURLAK

Wydział Nauk Pedagogicznych

Uniwersytet Kardynała Stefana Wyszyńskiego

Warszawa

ORCID ID: https://orcid.org/oooo-0oo2-1551-3699
Forum Pedagogiczne

9(2019) 2, cz. 1

Wpłynęło: 31.12 .2018

Zatwierdzono do druku: 26.06 .2019

DOI: $10.21697 / \mathrm{fp} .2019 .2 .20$

\title{
OVERCOMING SEXUAL ADDICTION: PECULIARITY, DYNAMICS OF DEVELOPMENT, CONSEQUENCES AND THERAPY
}

\begin{abstract}
The goal of this article is to show the peculiarity of sexual addiction - a manifestation of behavioral addiction - characteristics, specificity, dynamics of development, degrees of sex addiction, negative consequences for a person and her or his environment, families and relatives, and forms of therapy.
\end{abstract}

Key words: sexual addiction; specificity; forms of therapy.

\section{Introduction}

It is not that difficult to see that we have sexual revolution and changes of traditions, especially sexual that started in 50 of of the 2 oth century. And we still see the process of changes in American and European cultures. Sex has substituted a lot of values which had been recognized before. Sex became value in itself. Human being is impressed by the body, receiving pleasures through the body, so in the New Era the body became more important than the soul (Woźniak, 2012, p. 13). The most radical and revolutionary changes are introduced in life of a modern person via new technologies, computer, internet, cell phone, other devices which help us to penetrate into virtual reality. Technologies change traditions, including vision of love or the idea that is expressed with this word (Zwoliński, 2006, p. 131). It is worth highlighting that some modern people look for not only orgasm in sex, but also a confirmation that they are not lonely, needed, attractive, beloved, or valuable. Sex for some people becomes a way to cope with negative emotional states which are happening more and more often in these stressful times. Unfortunately, while trying to find new erotic impressions, people lose the most valuable part of close relationships - loyalty, tenderness, connection, mutual understanding, mutual assistance. Dissatisfaction from casual intimate relationships, a desire to experience 
more and more harsh and brutal sexual practices push some people on the path of searching for new partners and new dangerous forms of sexual behavior. They think that this path leads to higher self-esteem which would correspond with the image of modern macho, satisfaction, or the feeling of security and stability, dreamed happiness. But very often it is not true and those people have to experience another disappointment, loss of the illusion of love, and eventually, subjective suffering.

Anthony Giddens (2006, p. 102) is right when he writes that an attempt to be a sexual conqueror causes the same cycle of despair and disappointment as other addictions. Such an approach to intimate life will end up with exorbitant concentration of haphazard and uncontrolled sexual needs that become the sense of life. It can cause such a dangerous notion as sex addiction which has threatening consequences and is difficult to heal. The goal of this article is to show the peculiarity of sexual addiction - a manifestation of behavioral addiction - characteristics, specificity, dynamics of development, degrees of sex addiction, negative consequences for a person and her or his environment, families and relatives, and forms of therapy.

\section{The features of sex addiction syndrome}

When describing the syndrome of addiction to sex, it is worth emphasizing a number of its features and properties that determine the intensity of its manifestation. First of all the following phenomena must be assessed: frequency and type of sexual behavior, change in the amount of time spent on sexual practices, the effectiveness of attempts to control sexual behavior, manifestations of abstinence, denial of the problem, internal sexual coercion, restrictions of other interests, negative influence of sexual behavior on health, violation of moral and ethical principles, professional activity, unlawful conduct, and financial situation (MuldnerNieckowski, 2015b, p. 22).

Thanks to the research we can outline the following features of sex addiction: 1) the intensity and duration of sexual contacts goes far beyond the planned boundaries; 2) sexual behavior generates serious negative consequences; $3)$ the inability to get free of sexual behavior; 4) ignoring risky reality; 5) increased desire to control sexual behavior; 6) sexual obsession and fantasies as the basis of coping strategy; 7) increased sexual activity; 8) serious mood swings; 9) spending a huge amount of time to find sexual experiences, and toremedy a moral hangover; 10) neglecting of professional, social and sociable spheres of life; 11) desiring of sexual euphoria; 12) physical dependence, similar to narcotics; 13) craving or pathological desire, dissatisfaction leading to suffering; 14) withdrawal syndrome; 15) compulsive nature of the addiction; 16) the secret nature of addiction (caused by the fact that in our society people with sexual deviations must conceal their propensity because they fear mockery and condemnation); 17) changes in the personality that becomes infantile (a person cares only about their own needs); 18) a contradictory way 
of life; 19) introducing others to the role of the victim in the situation of violence; 20) lack of true proximity to the objects of sexual behavior; 21) perceiving other people as objects; 22) lack of the feeling of calmness, despair; 23) deepening of the feeling of shame; 24) deep fear (Guerreschi, 2012, pp. 71-72).

It is important to emphasize that those who engage in intense sexual activity, but also have an intensive activity in other spheres, be it professional, social, artistic, etc., are not recognized as those who have pathologically strong sexual desire. In this case it is simply a manifestation of great activity and the dynamism of their lives. It is only when the sexual need displaces all other social needs and forms of human activity we may talk about pathology. K. Imieliński (1985, p. 20) claims that it depends on traits of character, personality and peculiarity of the partnership (polygamous or monogamous way of life).

We cannot watch virtual sex carelessly. Compulsion of using pornographic virtual web pages and cybersex are often connected with illegal sex materials (child pornography, illegal services). So virtual sex seems to us more entertaining and more enjoyable than true sexual life, and reduces sexual contacts of the addict with a real sex partner (Zwoliński, 2014, p. 100). We need to highlight that there are children, young people, frustrated people (those who see subjectively or objectively impossibility to realize their wishes in reality), isolated, underestimated, with mental disorders, ill, those who were abused sexually in their childhood, or addicted to psychoactive substances in the risk group. For these people the virtual world is the only world where they can find understanding, boost their self-esteem, spot a right partner, "get rid of" sexual disorders, make their uninteresting life more colourful (Nowosielski, 2010, p. 290).

To conclude, it should be emphasized that the syndrome of addiction to sex has multiple symptoms. It has numerous features that relate to the appearance of eroticism in all spheres of psycho-social functioning of the individual - their thoughts, aspirations, motives, will, thinking, emotions and feelings, activity, traits of character, values, attitude towards themselves and other people. Under the influence of strong internal coercion, a sex addict continues a risky and devastating way of life that is extremely harmful to their psyche, health and social situation.

\section{Clinical signs of sex addiction}

The literature indicates the fact that sex can act as a kind of a drug. In this case, substances are produced inside the body in the form of naturally existing peptides endorphins that control electrochemical interactions in the brain. Their molecular structure is identical to the structure of opiates, such as morphine. Patrick Carnes (2001, p. 4) stressed that the whole avalanche of internal intoxication begins in human body as a result of capturing a new object of love. As the addiction develops, people are less interested in their partner. The only important thing is that 
partners help them to produce another portion of "drug" (endorphin), which gives a sense of pleasure (Gapik \& Waszyńska, 2006, p. 74). Each person, seeing someone attractive in front of him or her, can feel sexual exaltation or can have some fantasies. However, addiction to sex is characterized by the fact that sexual stimuli and properties of the human body are used to control the addict's mood and emotions. Over time, a person becomes dependent on psycho-biological reactions, so that sex ceases to be an activity of his or her own choice, but begins to function as a means of solving life problems. For some people, sex is a substitute for the preparation for pain, as well as a regulator of the level of tension and fear.

The search for new numerous sexual partners and the organization of visits with them is actively promoted by the so-called dating portals on the Internet: Amorandka.pl, Erodate.pl, Hellopl.com, LoveFactory.pl, Mydwoje.pl, Przeznaczeni. pl, Sexfotka.pl, Sympatia.onet.pl, Zbiornik.com that became a meeting place for people who are addicted to sex (Michalak, 2013, p. 33-37).

Individuals who exhibit harmful sexual behaviors usually have a double life with lots of unpleasant secrets. The detection of these secrets is a painful experience for the partner and other members of the family. The partner (usually a woman because men are more often addicted to sex) feels that she was betrayed and abandoned. Children feel that they were hurt (Grzegorzewska \& Cierpiałkowska, 2018, p. 346). The similarity of the clinical image of sexual addiction and the mechanism of the substance addiction is, in particular, in the fact that the sex addict feels all torments of drug craving: irritability, severe pain in muscles, insomnia, deconcentration, panic attacks, depression, suicidal thoughts (Gapik \& Waszyńska, 2006, p. 74).

\section{Degrees of sex addiction}

Therapists pay attention to three levels of sexual addiction. The first level occurs when a person stops controlling his or her sexual practices. In this case there is an obsessive masturbation. The relationship with a partner is limited to empty and depressing sexual relationships. The addicts intensively use pornographic material, as well as the services of prostitutes, make telephone conversations with obscene content in them, roam in places where "sexual intercourse" can appear (Guerreschi, 2012, pp. 73-74).

The second level of sexual addiction is manifested by harmful behavior prosecuted by law. Addicts perform actions in which there are victims (e.g. exhibitionism). It is one of sexual disorders that we can see more often than others and it covers 25-30\% of all behavior deviations (Lew-Starowicz, 1988, p. 134), including peeping, rubbing in a crowd off of other people.

The third level is a form of behavior that has serious legal consequences. These include rape, incest, sexual harassment, and the sexual exploitation of adults who are unaware of what is happening to them (Prajsner, 2013, pp. 8-9). The highest 
level of sex addiction involves not only amoral but also antisocial, illegal actions that are prosecuted by law.

\section{Dynamics of the development of the phenomenon of erotomania}

Sexual addiction has a dynamic and progressive character, observable to various degrees in all sex addicts. According to Niewiadomska et al. (2005, pp. 88-92) the dynamics of the dependencies addiction can be outlined in four phases:

Phase I - search for a pleasure. At this stage, a person experiments with sexual practices, feeling the state of pleasure. The main motives are the interest and the desire to get new experiences, boredom, the expectation of the reference group, the search for love and affinity, the desire to have a sense of security.

Phase II - pleasure causes a state of intoxication. A person who experiences pleasure tends to feel it stronger and stronger. Erotic ecstasy becomes part of everyday life. At the same time, toleration is growing: a person is looking for stronger arousals and new forms of satisfaction. A person begins to neglect their responsibilities, but is convinced that they still control the situation.

Phase III - the state of pleasure becomes the dominant goal. All functioning of a person is subordinate to the state of pleasure, which arises from erotic feelings. Gradually a person comes to the loss of control over behavior, to the abrupt abandonment of all aspects of human life. The motives of activity change because sexual acts arise from suffering, caused by the lack of erotic experiences. Active work of protective psychological mechanisms (denial and rationalization) allow perceiving the behavior as normal.

Phase IV - a state of intoxication from pleasure as a norm of functioning. Addicts fall into a vicious circle of "pleasure - disgust". A person feels the state of pleasure as a result of sexual acts and anguish when he or she lacks them. All other spheres of human activity remain beyond of person's consciousness. A person becomes selfish and concentrates on minimizing the bad state, by limiting their prosocial behavior, and sexual acts can become deviational (violence, pedophilia or zoophilia).

Psychologists (Carnes, 2010, p. 79-81; Guerreschi 2012, pp. 59-60) distinguish four stages of the development of cyclic experiences of each sexual phase:

a. trouble: this is a moment when the mind of the sex addict is completely focused on sex. P. Carnes (2010, p. 79) called this condition the trance. It causes an obsessive search for erotic stimuli;

b. ritualization: these are special habits, established in consciousness and the addict's behavior, preceding the sexual act;

c. compulsive sexual behavior: a sexual act is the ultimate goal and consequence of anxiety and rituals. The addict is not able to control or abandon a sexual act; 
d. despair: this is the feeling of a complete defeat that the sex addict experiences after a sexual act.

Every sexual phase in the life of a sex addict (regardless of which partner it is experiencing) ends in the same way, an unpleasant state of despair and a loss of hope for improvement.

\section{Consequences of sexual addiction}

A sex addict can experience the negative consequences in different spheres of life: 1) somatic health; 2) emotional state; 3 ) the cognitive sphere; 4) the financial condition; 5) social functioning. In the field of somatic health, an addicted person may develop sexual disorders (premature or delayed ejaculation, erectile dysfunction, anorgasmia), body trauma, and venereal disease. A sex addict also often suffers from peptic ulcer, high blood pressure, body depletion, appetite problems and sleep disturbances. Unsolicited pregnancy and abortion often occur among women.

Persons addicted to sex drown their true feelings reaching a state of apathy and neglect. Sex addicts are often infantile, impatient and demonstrate pretentious demeanor. They are suppressed by a sense of shame and hopelessness. Addicts live in a constant stress and are paralyzed by a fear of venereal diseases, especially AIDS, and the fact that their problem can be divulged. They can also exhibit helplessness, low self-esteem, depression, and even experience suicidal thoughts (Guerreschi, 2012, p. 93). The above is confirmed by Ryan (2014, p. 57) saying,

Every time I was subjected to fantasies and sexual behavior, a period of very strong oppression, I felt disgust for myself. Then I turned to God with a sincere request for forgiveness and help. I had the feeling that I was in a swamp from which I was struggling to extract my soul. After that, it was very difficult for me to focus on professional and family responsibilities.

Sex addiction also has significant negative consequences for mental processes. Sincerity, liveliness, sharp cognitive abilities undergo a significant deterioration. Thoughts about sex have a constant, obsessive character. Thinking is based on lies, self-justification, underestimation of risky situations; often, even cases of paranoid thoughts and persecutory delusion occur (Guerreschi, 2010, p. 169).

According to M. Lew-Starowicz (2018, p. 66) access to pornography can influence children who are in the stage of intensive psychosexual development. It can influence the creation of some scripts (socially accepted schemes of sexual behavior) which are going to create their future erotic life. As a result, a person can have a wrong image of sexual relations, standards of sexual needs and behavior of partner etc. that can cause vulgar perception of human sexuality (Pozdal, 2008, p. 124).

People addicted to sex also run into significant financial problems, since this kind of addiction brings about high financial costs resulting from payments for prostitutes' services or for access to pornography, from purchases of sexual instruments, visits to erotic massage parlors, night clubs, strip clubs and public 
baths. Sexual addicts spend a lot of money on paying for telephone sex lines, buying gifts to their lovers, fuel for cars that many use in search of new adventures, hotels they use for sex, legal services for divorce, etc. (Guerreschi, 2010, p. 166). They are also stripped off their savings in connection with numerous cases of blackmail, theft and the unauthorized use of their credit cards by dishonest sexual partners (Imieliński, 1990a, p. 108).

A person addicted to sex may lose their job because they cannot stay focused on their responsibilities (Guerreschi, 2010, p. 166). In the case of doctor, nurses, therapists, social workers, psychologists, sexual addiction can even lead to a complete loss of the right to exercise their professions (Imieliński, 199ob, s. 109).

Social problems are primarily related to family life (betrayal and scandals, loss of a regular partner, divorce, cases of family violence, irresponsible use of family budget, lack of time for family members, inability to provide proper education for children). Another harmful consequence of sexual addiction is the phenomenon of codependency of the wife of the erotomaniac. She is blamed for his condition and tends to overcontrol his behavior and gradually submits her entire life to the rhythm of the sex addict (Filarowska, 2011, p. 162). The addict gradually gets isolated from other important people-friends, colleagues at work. Sexually dependent are often in conflict with the law because of sexual harassment, rape or incest.

K. Imieliński (1990b, pp. 103-104) lists ten most painful losses erotomaniacs experience: 1) a loss of the most important relative (family, informal continuous relationship); 2) a loss of children (including abortion, termination of parental rights); 3) loss of important friends; 4) restricted access to their own children (including abandonment); 5) financial losses; 6) a feeling of guilt for hurting other people (including victims and sexual partners); 7) loss in productivity and creative skills; 8) career failure; 9) loss of integrity (together with damaging own values); 10) loss of self-respect.

Sexual addiction has also disastrous effect on spirituality of a person, his or her faith, relationship with God (Willingham, 2014, p. 32).

To sum up, sexual addiction is a very dangerous addiction that has a detrimental effect on all areas of psychosocial functioning of the addicted person and his or her environment. Because of pathological addiction to sex a person can lose calmness, well-being, reputation, family, friends, freedom, financial stability, health. And sometimes, when we talk about suicide or AIDS, even their life can be at risk.

\section{Therapy of sexual addiction}

In contrast to the therapy of substance addictions, which is aimed at complete abstinence, in the case of sex addiction, there is a return to normal sexual practices and healthy sexuality (Zdrada, 2017, p. 63). Individual or group therapy can be prescribed. Initially, patients are offered a retention of all sexual practices for a period of 30 to 90 days to ensure that they can do without sex (Guerreschi, 2010, 
pp. 172-173). However, life in abstinence for sex addicts is very difficult. Here's how 62-year-old addicted to pornography describes:

At the beginning of my treatment, for a long time, I felt as if I had fallen into a vicious circle. I watched pornography, then I felt very bad and promised that it would not happen again. After some time, I gave up, did it again and had a feeling of guilt and shame. After that, I repeated to myself that I would not do it again, and in the next few days I broke my promise again. (Maltz, Maltz, 2014, p. 184)

However, abstinence is also important because it is supposed to break the sexual trance. It helps to control your life, teaches to understand your sexuality and your needs (Prajsner, 2013, p. 9).

Patients with suicidal tendencies should be offered hospitalization. In some cases, psychotropic drugs are also used. Here is a more detailed analysis of various forms of help to a person addicted to sex.

Pharmacotherapy involves two different types of treatment: antiandrogens, as well as drugs that regulate emotionality, antidepressants and mood stabilizers, the so-called SSRI. This type of medication is usually used in psychiatry for the treatment of diseases such as obsessive-compulsive disorder or severe depression. The purpose of using these drugs is to reduce the increased sexual desire to a level that can be self-controlled (Guerreschi, 2012, p. 109; Lew-Starowicz 1985a, p. 114).

Psychotherapy makes it possible to establish long-term, trusting relationships between the addict and therapist. Thanks to them, the patient receives a particularly favorable opportunity to open to another person. An individual therapy should help an addicted person to overcome their isolation and change their attitude toward themselves and others (Roth, 2013, p. 147).

Psychotherapy of people with hypersexuality relies on three principles: 1) working with the mechanisms that are typical to the syndrome of addiction and striving to minimize risky behavior; 2) discovery of mental stress sources and searching for new ways to reduce it; 3) working on deeply-rooted personal difficulties (for example, working with problems in communication or minimization of harmful consequences of an inflicted psychiatric trauma) (Munder-Nieckowski, 2015a, p. 33).

When talking about psychotherapy of sex addicted, we need to realize that shame plays an important role in the process. So as the therapy begins, it is important to reduce a feeling of shame. The erotomaniac has to admit that his addiction is an illness and share their experience with the therapist (Smaś-Myszczyszyn, 2014, p. 46).

The process of psychotherapy of sexual addiction can be broken down into four stages: 1) initial intervention, 2) striving for abstinence; 3) in-depth work aimed at recognizing the function of excessive sexual activity in life of a patient and its replacement with healthy psychological activities based on various skills; 4) therapy that touches on the memories of previous sources of disorder, including partner therapy (Munder-Nieckowski 2015a, p. 33). 
Among the various forms of psychotherapy the most frequent are:

1. cognitive-behavioral therapy that observes psychological problems as mental disorders and aims to help assimilate relevant patterns of thinking and behavior through specific practical educational tasks (Guerreschi, 2012, p. 110);

2. group therapy where self-help groups for sex addicts rely on the 12-step program and act as models of Anonymous Alcoholics Groups. Such groups began their activities in the 6os in the United States, and later in the whole western world. There are four types: Sex Addicts Anonymous (SAA), Sex and Love Addicts Anonymous (SLAA), Sexaholics Anonymous (SA), and Sexual Compulsives Anonymous (SCA) (Guerreschi, 2012, pp. 110-114). Interestingly, members of the SLAA group may also be people who are emotionally dependent on their close relatives and not necessarily have sex problems (Roth, 2013, p. 158);

3. psychodynamic psychotherapy is usually applied to temper disorders. Among the main goals of such therapy for sexual addicts is the strengthening of self-control, as well as the development of skills to establish significant interpersonal contacts (Guerreschi, 2012, pp. 110-114);

4. therapy of trauma, the purpose of which is to bring the patient a sense of control over his or her own experiences and to create opportunities for patients to cope with their traumatic experiences (Roth 2013, p. 147);

5. marital psychotherapy not only helps to identify pathogenic factors in the family and figure out how the pathological behavior is reflected in the emotional and sexual problems of the family, but helps to motivate the partner to release the positive energy that has its place in life of a married couple (Guerreschi, 2012, pp. 110-115).

Doctors with different views unanimously believe that the complex nature of addiction to sex precludes the possibility of an underlying simple and homogeneous psychopathology. Therefore, in many cases, the best therapy seems to be based on an individualized combination of behavioral, psychosocial, psychodynamic and pharmacological approaches (Guerreschi, 2012, p. 116). It is also worth taking into account the fact that people with sexual addiction are those patients who often have a sexual dysfunction. They often do not function in a way that gives them and their partners sexual satisfaction. This is an indication that the use of multimodal therapy is essential for healthy intimate relationships (Dąbrowska, 2014, p. 173).

When discussing the problem of professional help for erotomaniacs, it's worth remembering that healing sexual addiction is a process that takes time. It is believed that it takes 5 years of sexual sobriety to achieve a qualitative change in the life of a sex addict who receives therapy. Not all patients get better in the same amount of time, but each of them passes through 6 phases of recovery:

1. the phase of maturation, where the addicts finally perceive that they have a problem. They are slowly experiencing a sense of helplessness, but they 
are not yet ready to disrupt completely this way of life and hope to solve the problem themselves.

2. the phase of crisis and decision in which sex addicts say that they cannot live longer this way.

3. the phase of shock when sex addicts give up on their practices, having noticed the harm they have caused to their professional and private life. At the same time, the feelings of despair and shame are becoming dominant.

4. the phase of regret, during which the addicts feel anger, pain and sorrow for the incurred losses. The feeling of pain they experience, makes them change their lives.

5. the phase of internal rehabilitation when the addicts understand that sexual addiction is something much more than just sexual behavior: it's life in a realm of illusions and negation, to which a patient completely subordinated his system of beliefs and values. At the beginning of this phase patient are primarily expected to regain the mental balance, and restore a structure in their daily affairs;

6. phase of growth, when the addicts become eventually ready to communicate with their loved ones. It is the time to find new ways for rebuilding interpersonal relationships (Prajsner, 2013, p. 9; Niewiadomska et al., 2005, pp. 178-179).

To summarize, addiction to sex is a disorder with complex etiology and a diverse symptomatology that may be associated with other sexual dysfunctions. This is why, pharmacological treatment and various types of therapy, both individual and group, are used. The complex nature of addiction to sex often requires multimodal therapy, and the process of getting out of this condition is long-lasting, complicated and can have recurrences.

\section{Conclusions}

Sexual addiction is an example of behavioral addictions mechanism of which is very similar to the dynamics of other addictions. Moreover, sexual addiction is often combined with other forms of addictive behavior (alcoholism, gambling, etc.), which has a complex nature and is a manifestation of the inability of an addicted person to adopt appropriate patterns of solving life problems. A key defining feature of sexual addiction is the painful, pathological desire for sexual intercourse. It strongly dominates all other needs, which not only significantly affects the sensory-emotional sphere of a person, but also their mental processes, will, values, and motivation for activity. In the end, this desire becomes the sense of life of an addicted individual. The compulsive, obsessive thoughts, aspirations and behavior of a sex addict change the intimate sphere of life, pleasant for most people, into a source of clinically significant subjective suffering. It becomes a way of relieving stress, fear, pain, and the method of solving life problems. 
People addicted to sex are unhappy. They keep searching for even more erotic experiences, they live a risky lifestyle in a community of immoral and marginalized individuals, isolate themselves from the most beloved and the closest friends and family, lose interest in professional activities, hobbies and vacations. They experience loneliness, fear, shame, depression. They feel that they are not loved and they also sometimes feel that they are unnecessary, having low self-esteem, and often suicidal thoughts. Their family ties are broken, the situation in the family and at work becomes complicated. They often have problems with somatic and mental health, break the law, or have financial problems.

Especially terrible is the impact of addiction to sex, including cyber sex, on adolescents and young people, as it forms negative models of intimate relationships that in the future may have very negative consequences for their outlook, hierarchy of values, as well as private, professional and social life.

Because of pessimistic and irrational beliefs, the distorted system of values and the compulsive behavior, sex addicts differ from those, who although engaged in intense sexual life, do not make a sexual life a sense of their existence. The difference is that the latter ones have an interesting job, meaningful life, a loving family, a group of friends, and are characterized by good health and high self-esteem. So, sex addicts are in a need for professional care, treatment and therapy. The process of recovery is long, complex, often characterized by relapse of the condition, so it takes a few years of considerable efforts, mobilization of willpower to overcome the disorder and stand on a path of moral and sexual recovery.

The problem of sexual addiction, due to its intimate and humiliating nature, is rarely included in school curricula, often due to insufficient training provided to educators, teachers, school psychologists, or social workers. For sex education directed at young people to be effective, it is necessary to invite qualified specialists sexologists, psychiatrists, psychotherapists, who have experience in handling sexual addictions. It is also necessary to offer in services to parents who, having no idea of behavioral addictions, cannot help their children, who, growing in a dangerous media environment, are in a high-risk group.

\section{References}

Carnes, P. (2001). Od nałogu do miłości: Jak wyzwolić się z uzależnienia od seksu i odnaleźć prawdziwe uczucie. Poznań: Wydawnictwo "Media Rodzina".

Carnes, P. (2010). Cyberseks. Skuteczna walka z uzależnieniem. Poznań: Wydawnictwo "Media Rodzina".

Dąbkowska, M. (2014). Zaburzenie hiperseksualne - aspekty historyczne, diagnostyczne i terapeutyczne. In K. Wasilewska-Ostrowska (Ed.). Praca socjalna z osobq uzależniona i jej rodzina. Wybrane problemy. Warszawa: Wydawnictwo "Difin". 
Filarowska, M. (2011). Po drugiej stronie lustra - czyli dramat współuzależnienia od seksu. In G. Iniewicz \& M. Mijas (Eds.). Seksualność człowieka. Wybrane zagadnienia. Kraków: Wydawnictwo Uniwersytetu Jagiellońskiego.

Gapik, L., \& Waszyńska, K. (2006). Uzależnienie od seksu. In L. Cierpiałkowska (Ed.). Oblicza współczesnych uzależnień. Poznań: Wydawnictwo Naukowe UAM.

Giddens, A. (2006). Przemiany intymności. Seksualność, miłość i erotyzm we wspótczesnych społeczeństwach. Warszawa: Wydawnictwo Naukowe PWN.

Grzegorzewska, I., \& Cierpiałkowska L. (2018). Uzależnienia behawioralne. Warszawa: Wydawnictwo Naukowe PWN.

Guerreschi, G. (2010). Nowe uzależnienia. Kraków: Wydawnictwo "Salwator".

Guerreschi, G. (2012). Uzależnienie od seksu. Kiedy seks może zabić. Kraków: Wydawnictwo Franciszkanów "Nowy Zew”.

Imieliński, K. (1984). Miłość i seks. Warszawa: Instytut Wydawniczy Związków Zawodowych.

Imieliński, K. (1985). Człowiek i seks. Warszawa: Instytut Wydawniczy Związków Zawodowych.

Imieliński, K. (1990a). Sekrety seksu. Warszawa: Instytut Wydawniczy Związków Zawodowych.

Imieliński, K. (199ob). Seksiatria. Patologia seksualna. Warszawa: Państwowe Wydawnictwo Naukowe.

Imieliński, K. (1992). Medycyna seksualna. Patologia i profilaktyka. Warszawa: Oficyna Wydawnicza Polskiego Czerwonego Krzyża.

Lew-Starowicz, M. (2018). Kochanie czy klikanie. Terapia dla zagubionych kobiet i mężczyzn. Bielsko-Biała: Wydawnictwo "Pascal".

Lew-Starowicz, Z. (1985). Leczenie czynnościowych zaburzeń seksualnych. Warszawa: Państwowy Zakład Wydawnictw Lekarskich.

Lew-Starowicz, Z. (1988). Seks nietypowy. Warszawa: Instytut Wydawniczy Związków Zawodowych.

Maltz, W., \& Maltz, L. (2014). Pułapka porno. Jak uwolnic się z uzależnienia od pornografii. Poznań: Wydawnictwo "Media Rodzina".

Michalak, M. (2013). Portale randkowe miejscem spotkań ludzi uzależnionych od seksu - specyfika zjawiska. Maszynopis pracy magisterskiej napisanej pod kierunkiem A. Fidelus. Warszawa: Uniwersytet Kardynała Stefana Wyszyńskiego.

Muldner-Nieckowski, Ł. (2015a). Kluczowe problemy w terapii osób uzależnionych od aktywności seksualnej. Świat Problemów, 11.

Muldner-Nieckowski, Ł. (2015b). Różne oblicza seksoholizmu. Rozpoczynanie terapii osób pochłoniętych nadmierną aktywnością seksualną. Świat Problemów, 3.

Niewiadomska, I., Chwaszcz, J., Kołodziej, B., \& Śpila, B. (2005). Seks. Lublin: Wydawnictwo Katolickiego Uniwersytetu Lubelskiego.

Nowosielski, K. (2010). Cyberseksualność. In Z. Lew-Starowicz, V. Skrzypulec (Eds.). Podstawy seksuologii. Warszawa: Wydawnictwo Lekarskie PZWL. 
Penix Sbraga, T., \& O’Donohue, W. (2003). Jak pokonać uzależnienie od seksu? Trening. Gliwice: Wydawnictwo "Helion".

Pozdal, M. (2008). Cyberseks - nowe możliwości i zagrożenia. In A. Jodko (Ed.). Tabu seksuologii. Warszawa: Wydawnictwo "Academica”.

Prajsner, M. (2013). Kiedy przyjemność staje się niebezpieczna. Remedium, 1.

Roth, K. (2013). Ciemna strona seksu. Gdy seks staje się nałogiem. Gdańsk: Gdańskie Wydawnictwo Psychologiczne.

Ryan, T. (2014). Już się nie wstydzę. Wyznania mężczyzny uzależnionego od seksu. Poznań: Wydawnictwo "W Drodze".

Smaś-Myszczyszyn, M. (2014). Miejsce wstydu w terapii osób uzależnionych od seksu. Świat Problemów, 4.

Willingham, R. (2014). Uwolnij się! Uzależnienie seksualne i uzdrawiająca moc Jezusa. Kraków: Wydawnictwo "Esprit".

Woźniak, K. (2012). Seks i seksualnośćw dobie ponowoczesności. Opole: Wydawnictwo Naukowe Scriptorium.

Zdrada, D. (2017). Seksoholizm - perwersja i miłość. Warszawa: Wydawnictwo Difin.

Zwoliński, A. (2006). Seksualność w relacjach społecznych. Kraków: Wydawnictwo WAM.

Zwoliński, A. (2014). Cyberseks. Kraków: Wydawnictwo Petrus.

\section{POKONAĆ SEKSOHOLIZM - SPECYFIKA ZJAWISKA, DYNAMIKA ROZWOJU, KONSEKWENCJE I TERAPIA}

Streszczenie: Celem niniejszego artykułu jest ukazanie specyfiki uzależnienia seksualnego, a w szczególności opisanie jego przejawów, cech konstytutywnych, specyfiki, dynamiki, stopni uzależnienia od seksu, negatywnych konsekwencji, w tym nie tylko wobec osoby uzależnionej, lecz również jej środowiska, rodziny i krewnych, oraz form terapii.

Słowa kluczowe: seksoholizm; specyfikacja; terapia.

Iryna Kurlak - profesor, doktor habilitowana, zatrudniona w Katedrze Resocjalizacji i Profilaktyki Społecznej Uniwersytetu Kardynała Stefana Wyszyńskiego, autorka ponad 160 prac naukowych, w tym czterech monografii, m.in.: Podstawy pedagogiki opiekuńczej (Lwów 2015; w języku ukraińskim), Pedagogika postpenitencjarna: zasady teoretyczne i realia praktycznego zastosowania $w$ Polsce (Lwów 2010; w języku ukraińskim). Adres do korespondencji: Wydział Nauk Pedagogicznych, ul. Wóycickiego 1/3, 01-938 Warszawa. Adres e-mailowy: i.kurlak@uksw.edu.pl. 